\title{
Plants with known antagonistic properties against pests: how they influence non-target free-living soil fauna?
}

\author{
Krassimira Ilieva-Makulec*, Michał Bielecki, Grzegorz Makulec \\ Institute of Ecology and Bioethics, Faculty of Christian Philosophy, \\ Cardinal Stefan Wyszyński University, Wóycickiego 1/3 \\ 01-938 Warsaw, Poland, k.makulec@uksw.edu.pl
}

\begin{abstract}
Summary
The aim of the study was to investigate the effect of three plant species with known antagonistic properties against pests on selected free-living species of soil fauna. The direct effects of aqueous extracts (from hemp leaves and garlic pulp) on the survival of representatives of nematodes, potworms and earthworms were studied. In the case of nematodes, the effects of hemp extracts on the egg production, total fertility and juvenile hatching efficiency were also assessed. Moreover the indirect plant impact (in the form of hemp litter added to the soil or through the root system during planting of castor bean) on soil nematodes was studied.

The results of the bioassays confirmed the antagonistic effect of the plant extracts. The most sensitive to the hemp extract toxicity were nematodes, less potworms and at least earthworms. The toxicity of the hemp extract showed a clear dependence on its concentration. The garlic extract showed less toxicity to nematodes than the hemp extract did. The incubation of nematode females in the hemp extracts of different concentrations affected the rate of egg laying, the length of reproduction period and the hatching efficiency but did not affect their overall fertility. In soil, both the hemp litter and the castor plants had a positive indirect effect on the numbers of nematodes at least during the experiment.
\end{abstract}

\section{Key words}

plant extracts, bacterial-feeding nematodes, potworms, earthworms, biotests, micro- and mesocosms

\section{Introduction}

To reduce the environmental risks associated with the use of pesticides, some of them are legally banned or their production withdrawn. Due to the limited use of synthetic pesticides, there is a real need to replace them with plant-based substances, theoretically considered to be more environmentally friendly. Many studies have shown that different active substances (phenolic acids, flavonoids and aromatics, including terpenoids, steroids, alkaloids and cyanides) found in plant products (originating from the aboveground parts, roots or seeds) may influence the target organism by repelling or attracting, may interfere with pest reproduction, inhibit its growth, egg laying process, hindering the penetration of plant tissues, reducing the feeding activity, and eventually causing toxicity and leading to its death. 
There is a lot of information on the effectiveness of various plant products in the control of certain pests and plant diseases. Plant products can be an alternative to synthetic pesticides only if their use is equally effective but more environmentally safe. It is therefore important to investigate the effects of plant products not only on target (pest) organisms.

So far, the results of many studies have demonstrated the antagonistic properties of various plant extracts against different plant parasitic nematodes (Grewal 1989, Wuyts et al. 2006, Thoden et al. 2007, Seenivasan 2011, El-Nagdi et Youssef 2013, Chałańska et al.). However there is scarce information about the effects of plant extracts on non-target organisms e.g. freeliving nematodes (Akhtar and Mahmood 1993, Seenivasan et al. 2013, Ritzinger et al. 2014) or other representatives of soil fauna (e.g. earthworms and potworms), which play an important role in the soil environment and the processes taking place there

The aim of this study was to investigate the effect of several plants with known antagonistic properties against pests on selected free-living species of soil animals. Three plant species (hemp Cannabis sativa L., garlic Allium sativum L. and castor bean Ricinus communis L.) whose efficacy in combating parasites has been confirmed in many works (Seenivasan 2011, Chałańska et al. 2013, El-Nagdi and Yossef 2013) were used.

Industrial hemp is one of the oldest cultivated plant species in the world, not only because of its use in textile industry, but also because of its rich chemical composition. These plants contain over 4 oo chemical compounds, for example, cannabinoids, flavonoids, dihydrostilenes, or phenanthrenes (Rutkowska and Jamontt 2005). It was shown that hemp extracts, similarly to some synthetic substances, act as a deterrent to plant parasitic nematodes (Siudem et al. 2015).

Garlic is a common plant found in many parts of the world. Due to its chemical composition it has long been used as a crop protection agent. It contains sulphur glycosides, flavonoids, phytosterols, sugar compounds, sulphides and trace elements - Mg, Fe, Zn, Mn, B, Cu. An important substance is allicin, which combines bactericidal and hypoglycaemic properties. Already small amounts of allicin reduce microbial activity in the environment in which it occurs (Kemper 200o).

Castor bean is a plant grown mainly in low and medium developed countries. The ricin it contains is a known strong toxin, causing extensive symptoms in humans as well as in animals. Absorbed by the cell the ricin gets into the lysosomes acting destructive to their function (Borek and Galor 2015).

The aim was to investigate the impact (direct and indirect) of the selected plants on representatives of three groups of soil fauna (bacterial-feeding nematodes, potworms and earthworms). Bacterial-feeding nematodes are known to influence the numbers, activity, and distribution of bacteria in soil and thus affect the rate of decomposition and mineralization, which in turn may have an impact on plant productivity (Ilieva-Makulec 2013). The potworms and earthworms feed on decomposed litter. Their main role in the environment is the mineralization and humification of organic matter and $\mathrm{N}$ transformations in the soil (Makulec and Ilieva-Makulec 2013).

Our work hypotheses assumed that the plant extracts would be antagonistic to the selected soil organisms. Moreover, it was expected that: i) the effect of the plant extract will depend on its concentration and species of plant; ii) The plant effect will be stronger in water than in the soil.

\section{Material and methods}

\subsection{Studied animal species}

The study was based on representatives of soil: microfauna - bacterial-feeding nematodes belonging to Acrobeloides nanus (reared in Petri dishes on $2 \%$ agar with boiled egg yolk); mesofauna - potworms 
Enchytraeus sp., and macrofauna - earthworms Dendrobaena sp. (both purchased at a local pet shop).

\subsection{Studied plant species}

In our experiments, leaves, shoots or seeds of the following plants were used: hemp Cannabis sativa L. (the hemp leaves were derived from plants cultivated on the experimental field of the Agricultural Advisory Centre in Płońsk); garlic Allium sativum L. with organic farming origin; castor Ricinus communis L. (seeds purchased from a vegetable market). Plants have been selected on the basis of certain characteristics such as the frequency of occurrence and the content of compounds that can be described as toxic or selectively toxic to soil pests (Kemper 2000, Rutkowska and Jamontt 2005, Borek and Galor 2015). Birch Betula sp. (leaves collected in the woods) and lupine Lupinus sp. (seeds purchased from a vegetable market) were used as control plants in the micro- and mesocosms, respectively.

\subsection{Preparation of aqueous extract of hemp leaves}

Dry hemp leaves after grinding were used to prepare the extract. $200 \mathrm{ml}$ of distilled water was added to $10 \mathrm{~g}$ of dried leaf material and left in the dark for 72 hours at room temperature. The mixture was then heated to $30^{\circ} \mathrm{C}$ and filtered. Thus a $5 \%$ extract was obtained. Later, after two serial dilutions $2.5 \%$ and $1.25 \%$ extracts were prepared.

\subsection{Preparation of aqueous extract from garlic pulp}

The extract was prepared from $10 \mathrm{~g}$ finely chopped cloves of garlic. $50 \mathrm{ml}$ of distilled water was poured on garlic pulp and allowed to stand for 24 hours in the dark, at room temperature. After filtration, an extract of $20 \%$ was obtained. The $10 \%, 5 \%, 2.5$ and $1.25 \%$ extracts were prepared using the dilution method.

\subsection{Direct effects of plant extracts - biotests}

\subsubsection{Effect of aqueous extracts of hemp} and garlic on the survival of nematodes belonging to the species Acrobeloides nanus

The study was carried out on watch glasses, enclosed within Petri dishes. One $\mathrm{ml}$ of previously prepared aqueous extract with specified concentration $(5 \%, 2.5 \%$ and $1.5 \%)$ was poured into glasses. Five individuals of Acrobeloides nanus were then introduced to each glass. In the control, distilled water was used instead of hemp extract. Each variant had 5 replicates. Observations were performed under stereoscopic microscope every half an hour for 4 hours or until nematodes were not able to perform any movements when touched with a needle.

Studies on the impact of garlic extract on the nematodes were performed in the same way as for hemp, with two additional concentrations $-10 \%$ and $20 \%$. The observations were carried out under stereoscopic microscope every hour for 5 hours.

\subsubsection{Effect of hemp aqueous extracts on the survival of potworms Enchytraeus sp.}

Two ml of extract at a specified concentration $(5 \%$ or $2.5 \%)$ were poured into watch glasses and then 3 potworms were introduced. The control variant contained only water. In each variant there were 5 replications. The observations were carried out under stereoscopic microscope every half an hour for 4 hours.

\subsubsection{Effect of hemp aqueous extracts on the survival of earthworms Dendrobaena sp.}

The effect of hemp extract on earthworms was tested on a filter paper soaked with 5 $\mathrm{ml}$ extract (of $5 \%$ and $2.5 \%$ concentration) and placed in a Petri dish. $5 \mathrm{ml}$ of distilled water was used in the control variant. One worm was introduced into each dish and each variant was done in 5 replications. The observations were performed every hour for 4 hours under a stereoscopic microscope. 


\subsubsection{Egg production and fertility of $A$. nanus females after incubation in hemp extract}

Young females incubated previously in hemp water extracts of $1.25 \%, 2.5 \%$ and $5 \%$ concentration were used for the study. In the control variant, the females were kept in distilled water. After 4 hours (but only 30 minutes in $5 \%$ extract) of incubation, the nematodes were transferred to the distilled water. One hour later, the individuals able to perform movements were transferred to watch glasses (with $2 \mathrm{ml} 2 \%$ agar) enclosed within Petri dishes. The dishes were stored in a climate chamber at $200 \mathrm{C}$ and $70 \%$ humidity. Every day the laid eggs were counted and the females were transferred to new watch glasses. The observations lasted for 19 days and were performed under a stereoscopic microscope. Ten replicates were prepared for each variant.

\subsubsection{Effect of hemp water extract on $A$. nanus egg hatching efficiency}

The experiment was conducted in two ways In the first case, $A$. nanus females were firstly incubated for 4 hours in $1.25 \%, 2.5 \%$ and only for $30 \mathrm{~min}$ in $5 \%$ hemp aqueous extracts and then transferred to water for 1 hour. Females able to perform movement were transferred by pipette onto watch glasses with $2 \mathrm{ml}$ of $2 \%$ agar where they were allowed to lay eggs. The glasses were enclosed within Petri dishes and placed in a climate chamber at $200 \mathrm{C}$ and $70 \%$ humidity. The observations were performed daily during the week under a stereoscopic microscope. After being counted, juveniles were removed from the glasses. Ten replicates were prepared for each variant.

In the second case, eggs deposited by females (which had not previously been exposed to hemp extract effect) in water were quickly transferred to watch glasses with $2 \mathrm{ml}$ of hemp extract of different concentrations of $1.25 \%, 2.5 \%$ and $5 \%$, or to glasses with only water (in the control). The observations were performed daily under stereoscopic microscope. Juveniles, after counting, were removed from the glasses. The experiment lasted for a week. Ten replicates were prepared for each variant.

\subsection{Indirect plant effect on soil micro-fauna - micro- and mesocosms}

\subsubsection{Effect of plant litter on the abundance of bacterial-feeding nematodes - microcosm studies}

The experiment was conducted in 20 plastic boxes (microcosms) with a volume of $60 \mathrm{ml}$. Sand ( $50 \mathrm{~g}$ ) was added to each box. Then 0.5 $\mathrm{g}$ of ground birch leaves were added to the half microcosms and $0.5 \mathrm{~g}$ of dry grounded hemp leaves were added to the other half. The litter was mixed with the sand. Ten $\mathrm{ml}$ of distilled water was added to each box to ensure proper humidity. The experiment was conducted in two variants: i) $1 \mathrm{ml}$ of aqueous suspension containing 120 nematodes (A. nanus) was added to the microcosms with hemp leaf litter; ii) $1 \mathrm{ml}$ of aqueous suspension containing 120 nematodes (A. nanus) was added to the microcosms with birch litter. Nematodes $A$. nanus came from laboratory culture (rared on agar) and were extracted into water by the Baermann method (Flegg and Hooper 1970).

Both types of litter, before being added to microcosm, were dried for one day at $60^{\circ} \mathrm{C}$ to eliminate soil fauna. Each variant was performed in 10 replications (microcosms). Twice, after 45 and 70 days, the number of nematodes was determined in 5 microcosms of each variant. For this purpose, nematodes were counted under a stereoscopic microscope after the extraction from soil.

\subsubsection{Indirect effects of plants (castor bean and lupine) grown in pots on soil nematodes - mesocosm studies}

Twenty pots with $1250 \mathrm{~g}$ of garden soil each were prepared. Half of the pots were planted with 3 lupine seeds, and the other half with 3 castor seeds. Samples were taken twice: 45 and 65 days after the start of the experiment. Three sampling zones were identified: root zone ( $\mathrm{R}$ - root samples), rhizosphere ( $\mathrm{Rh})$, i.e. soil layer distant $1.5 \mathrm{~cm}$ from the root 

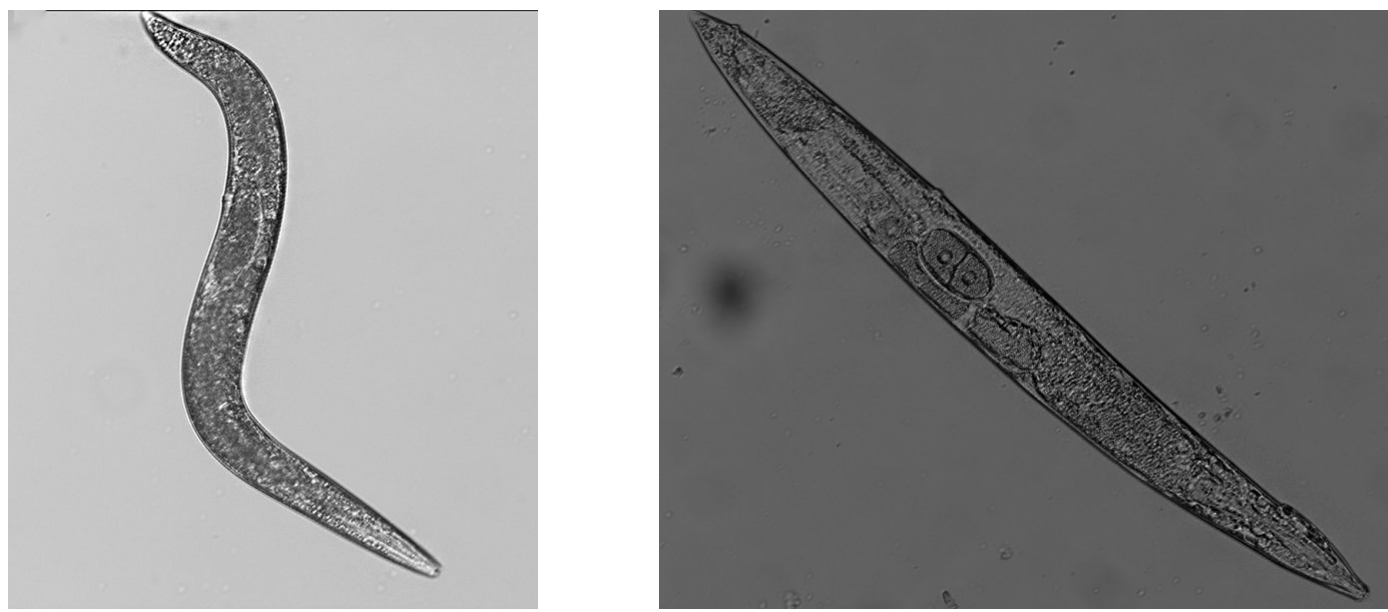

Photo 1. Alive (on the left) and dead (on the right) nematode after incubation in hemp water extract

axis and remaining soil (S). At each sampling date, 3 soil samples (S) and 5 samples from the other two zones ( $R$ and $R h$ ) were collected. Soil samples from zones Rh and $\mathrm{S}$ were taken with a soil corer. The Baermann method was used to extract nematodes. The roots samples before the extraction were cut into 1-2 $\mathrm{cm}$ pieces. After extraction, nematodes were counted under a stereoscopic microscope.

\subsection{Statistical analysis}

In order to compare the effects of different concentrations of plant extracts on such parameters as nematode survival, egg production and hatching efficiency, a chi-square test was used. Calculations were made using an interactive tool (Preacher 2001).

Because, the data for nematode densities (from micro- and mesocosm experiments) does not correspond to the normal distribution, the significance of differences between different variants was checked by the non-parametric Mann-Whitney test. The analysis was done in STATISTICA (StatSoft, Inc. 2014)

\section{Results}

\subsection{Direct effect of hemp extracts on the survival of nematodes of the A.nanus}

Our results indicate a statistically significant ( $p<0.001$ ) negative dependence of nematode survival on the concentration of hemp leaf extract (Photo 1). Values of $\mathrm{c} 2$ ranged from 22 (after 30 minutes) to 174 (after 4 hours). Nematodes showed the greatest sensitivity in relation to the highest concentration. Almost $100 \%$ mortality was reported after an hour of exposure in a $5 \%$ solution (Fig. 1). A significant decrease of nematode survival was observed in $2.5 \%$ extract. After an hour, only $40 \%$ of the tested animals showed life functions. This percentage decreased with time, and after 4 hours, only $6 \%$ of nematodes were still alive (Fig. 1).

The $1.25 \%$ hemp extract was found to have the weakest effect on the nematodes. After 1.5 hour of exposure, as much as $83 \%$ of the nematodes retained their life functions and at the final observation $40 \%$ of tested animals were still alive. The loss of motor activity (paralysis) seen in some individuals was found to be transient (Fig. 1). In the control, $100 \%$ of nematodes survived during the 4-hour observation (Fig. 1). 


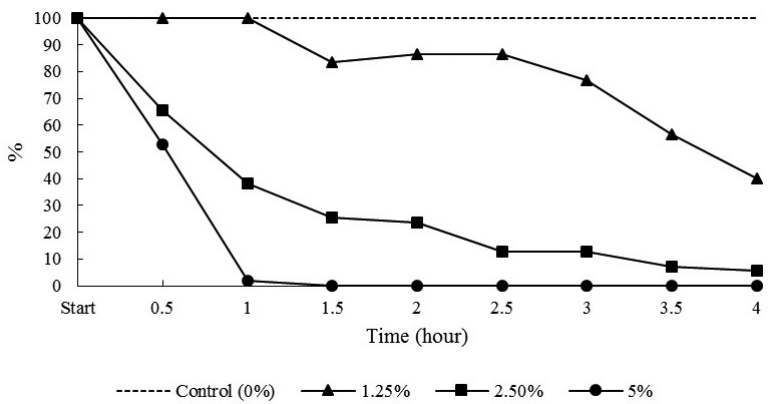

Fig. 1. Survival (in percent) of nematodes (Acrobeloides nanus) in hemp extracts of different concentrations

Fig. 2. Survival (in percent) of potworms (Enchytraeus sp.) in hemp extracts of different concentrations
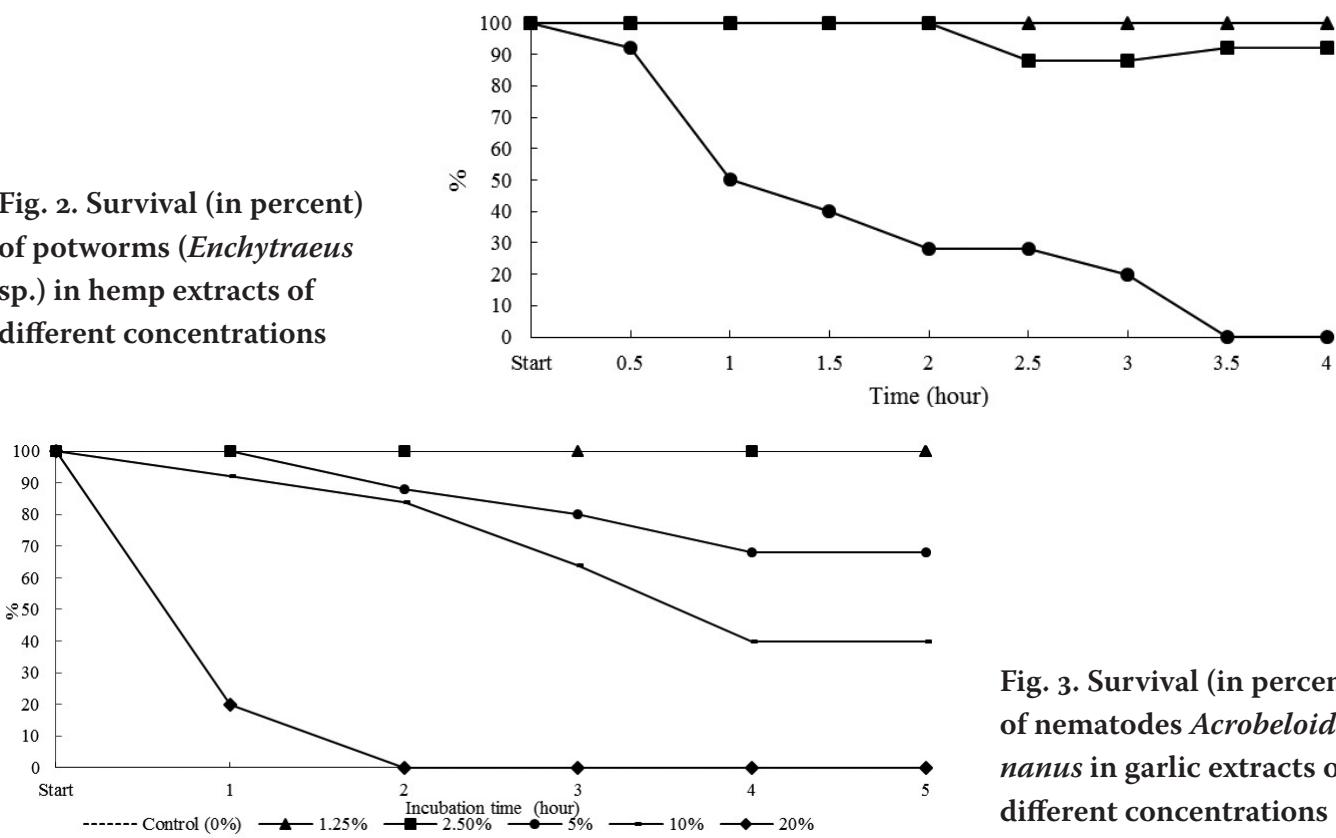

Fig. 3. Survival (in percent) of nematodes Acrobeloides nanus in garlic extracts of different concentrations

\subsubsection{Direct influence of hemp extracts on the} survival of potworms of Enchytraeus sp.

The hemp extract at a concentration of $5 \%$ was found to be more toxic for the potworms than $2.5 \%$ extract In time between 30 and 60 minutes the potworm survival dropped from 90 to $50 \%$. Mortality of $100 \%$ was observed after 3.5 hours. The extract at a concentration of $2.5 \%$ slightly affected the vital functions of potworms. After four hours of exposure, nearly $90 \%$ of the individuals were still alive (Fig. 2). Hemp extract of $1.5 \%$ did not effect potworms. No mortality of animals was observed in the control.

\subsubsection{Direct influence of hemp extracts on the survival of earthworms of Dendrobaena sp.}

There was no effect of aqueous hemp extract on earthworms ( $p>0.05$ ). Regardless of the concentration of the solution $(2.5 \%$ or $5 \%$ ) no mortality was found in the experimental animals and therefore not refer graph.

\subsubsection{Direct effect of garlic extracts on the survival of nematodes of Acrobeloides nanus}

Garlic extract at a concentration of $20 \%$ had the greatest negative effect on the nematodes ( $p<0.05)$. Absence of visible life functions was found in all nematodes after two hours of exposure (Fig. 3). In the 10\% solution the nematodes survived longer - after 


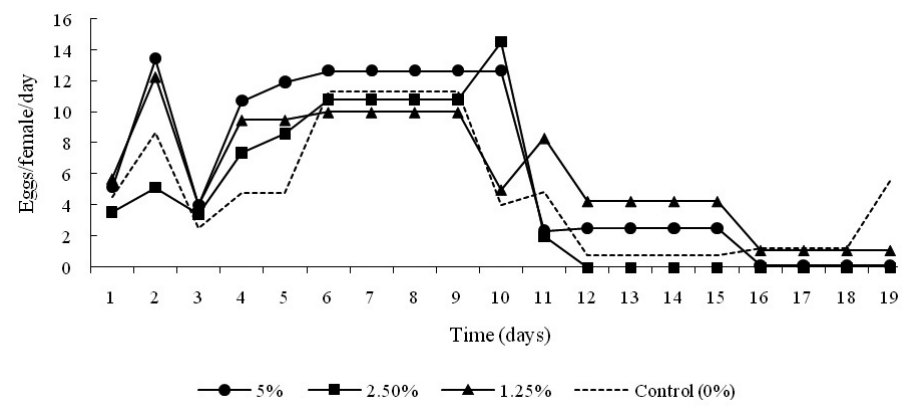

Fig. 4. Egg production of Acrobeloides nanus females after incubation in hemp extracts of different concentrations

Fig. 5. Total number of eggs produced by $A$. nanus females after incubation in hemp leaf extracts of different concentrations

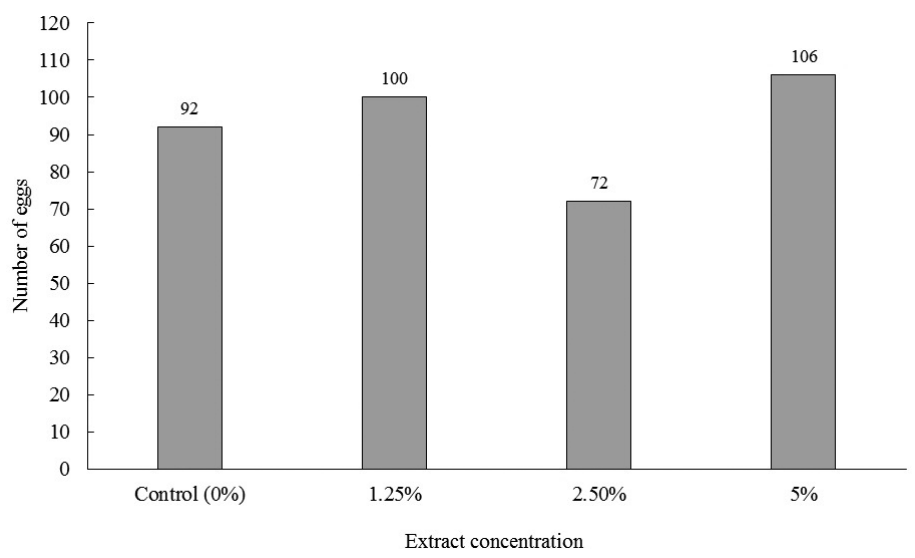

4-5 hours $40 \%$ of the individuals were still alive (Fig. 3). The 5\% extract slightly decreased nematode survival $-70 \%$ of nematodes were still alive even after 5 hours of incubation. No negative effects on nematode survival were observed in variants with a concentration of $2.5 \%$ and $1.25 \%$ (Fig. 3).

\subsubsection{Effect of hemp leaf extract on egg production dynamics of Acrobeloide nanus females}

The dynamics of egg production in A. nanus females was similar in all variants irrespective of the concentration of the extract in which the females had stayed before the start of oviposition. However, a trend of a greater intensity of this process in pretreated females compared to control females was observed. The daily number of eggs laid by treated females was most often greater than the number of eggs laid by a female from the control (Fig. 4). The length of egg production period depends on the concentration of the extract in which the females were incubated previously. Females from the $5 \%$ extract ended up the egg laying faster (after 12 days) than the females from the $2.5 \%$ extract (after 16 days). Females from the $1.25 \%$ extract and the control ones did not complete the egg reproduction within the experimental time. In the control, there was even an increase in the daily number of eggs at the end of the observation.

\subsubsection{Effect of hemp leaf extract on fertility of Acrobeloides nanus females}

The highest number of eggs (within the experimental time) was produced by females incubated in a $5 \%$ extract - over 100 eggs, and the lowest number by females in a $2.5 \%$ extract -72 eggs (Fig. 5). No significant effect of the hemp extract concentration on total fertility $\left(\mathrm{chi}^{2}=7.1, \mathrm{p}>0.05\right)$ was found.

\subsubsection{Effect of hemp extract on the $A$. nanus juveniles hatching efficacy}

The results indicated that the hatching efficiency depended on whether the eggs came from the females early incubated in the extracts 


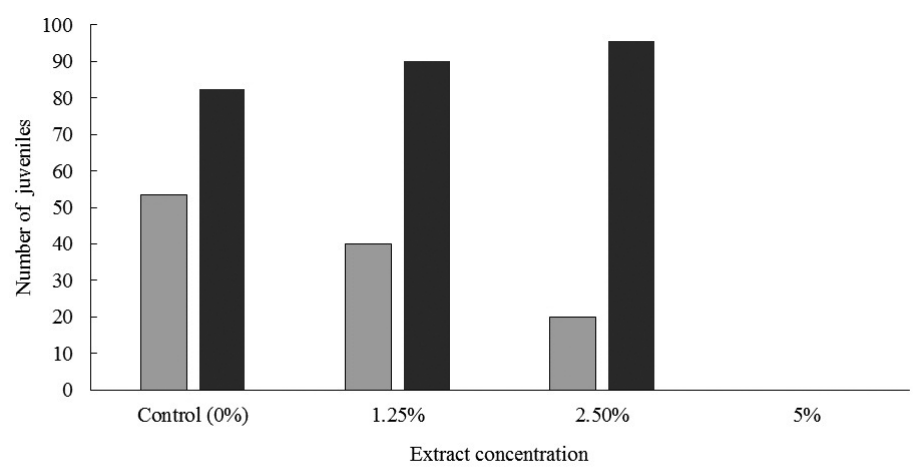

$\square$ juveniles from eggs, which females laid on agar after incubation in hemp extracts

- juveniles from eggs deposited by females directly into the extracts
Fig. 6. Effect of hemp extracts on the Acrobeloides nanus juveniles hatching efficacy

Fig. 7. Population dynamics of Acrobeloides nanus in soil enriched with hemp litter. Mean values \pm SD are given
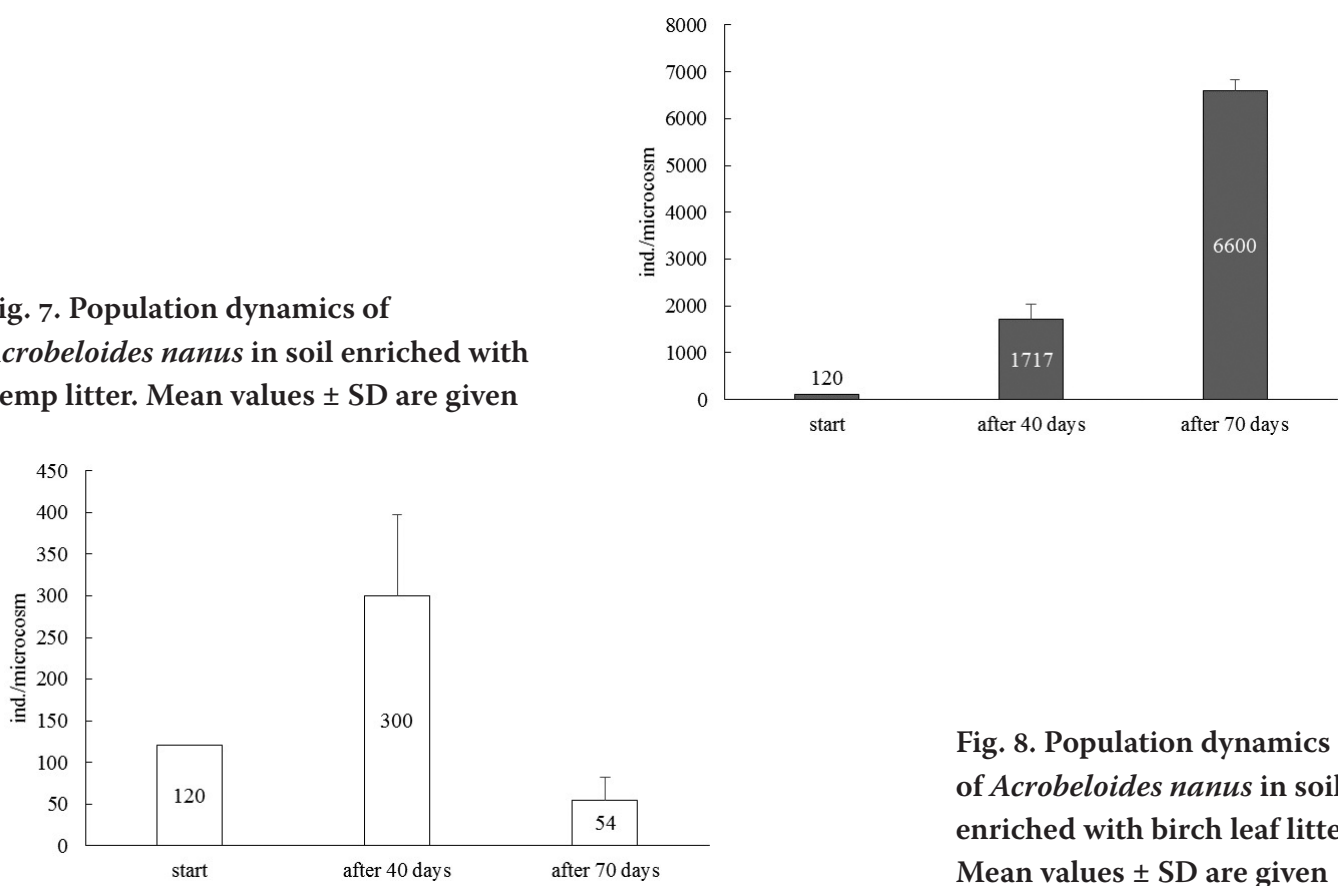

Fig. 8. Population dynamics of Acrobeloides nanus in soil enriched with birch leaf litter. Mean values \pm SD are given

or the eggs were deposited directly by females into the extract. The efficiency of hatching in the case of previously incubated females decreased significantly as the concentration of extract increased $\left(\mathrm{chi}^{2}=66 ; \mathrm{p}<0.001\right)$ (Fig. 6).

Such a dependency of hatching efficiency was not found for eggs that the females deposited directly in the extracts. In this case, extracts of $1.25 \%$ and $2.5 \%$ were stimulating for hatching process - more juveniles were found than in control (Fig. 6). However, there was no significant difference between control, $1.25 \%$ and $2.5 \%\left(\mathrm{chi}^{2}=1, \mathrm{p}=0.61\right)$.
The $5 \%$ extracts in both cases were found to have a significant inhibitory $(\mathrm{p}<0.05)$ effect on the hatching (Fig. 6).

\subsection{Effect of plant litter on the abundance of bacterial-feeding nematodes of Acrobeloides nanus - microcosm studies}

The results show an increase in the numbers of nematodes after 40 days in both types of litter (Figs 7 and 8). This increase was tenfold in case of hemp litter and only threefold in the case of birch litter. Hence, the difference in the number of nematodes between 


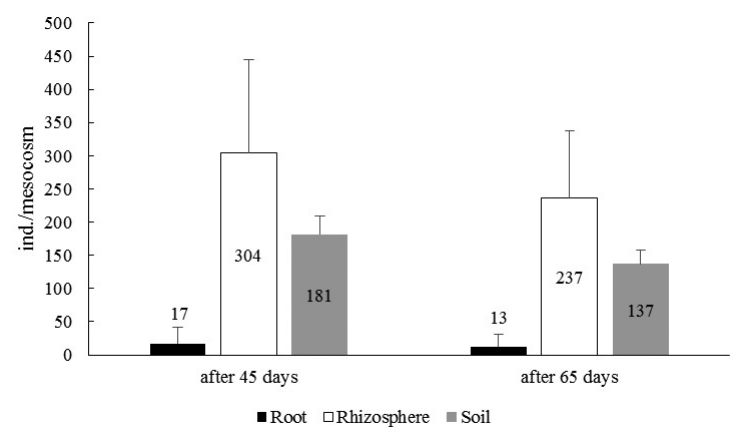

Fig. 9. Nematode abundance in mesocosms with planted lupine. Mean values + SD are given

Fig. 10. Nematode abundance in mesocosms with planted castor. Mean values $+\mathrm{SD}$ are given

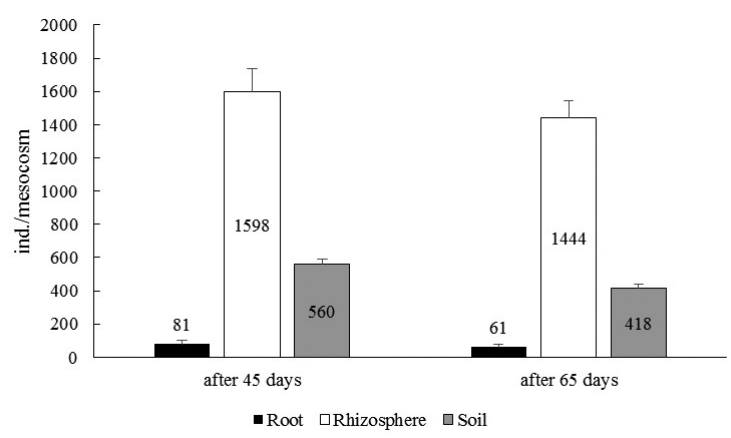

the two variants was statistically significant $(p=0.05)$. After 70 days there was a further increase in the number of nematodes in microcosms with hemp litter, while a large, as much as sixfold decline in microcosms with birch litter (Figs 7 and 8). At that time, the number of nematodes in microcosms with hemp litter was significantly higher $(p=0.02)$ than in the birch variant.

\subsection{Indirect effects of two plants (castor bean} and lupine) grown in pots on soil nematodes mesocosms studies

On both sampling dates for both test plants, nematode numbers were the lowest in the roots and the highest in the rhizosphere (Figs 9 and 10). The differences in the number of nematodes between the three zones for each plant were statistically significant $(\mathrm{p}<0.05)$. In each zone significantly higher abundances ( $\mathrm{p}<0.05$ ) were found in the mesocosms with castor than with lupine.

\section{Discussion}

The efficiency of plant products in controlling plant pests and diseases has been the subject of many studies. Up to now the results have confirmed the antagonistic properties of some plant extracts in relation to different nematode species known to be plant parasites causing high losses in plant production (Grewal 1989, Wuyts et al. 2006, Thoden et al. 2007, Seenivasan 2011, El-Nagdi and Youssef 2013, Chałańska et al. 2013). So far, there is scarce information on the effects of plant extracts on non-target organisms such as free-living nematodes (Akhtar and Mahmood 1993, Seenivasan et al. 2013, Ritzinger et al. 2014) or other representatives of soil fauna (e.g. earthworms and potworms) which play an important role in the soil environment and the processes taking place there.

\subsection{Direct effect of water extract of garlic pulp and hemp leaves on soil animals}

Our results indicate an antagonistic activity of tested plant extracts but not in all cases. Some differences in the hemp extract influence on the survival of the studied animal species were found. The microfaunal representatives, i.e. the bacterial-feeding 
nematodes $A$. nanus were the most susceptible to the active substances of the extract , followed by the potworms Enchytraeus sp. and the earthworms Dendrobaena sp. were the most resistant. The aqueous hemp extracts at tested concentrations showed toxicity to nematodes and potworms, but no adverse effects were observed on earthworms. This could be explained by the differences in the size of the studied animals and their metabolic rates. Sensitivity of nematodes can be also attributed to the high permeability of their cuticle, so they are in direct contact with the toxic substances (Nicholas 1975).

In the case of nematodes and potworms, the extract toxicity was found to be strongly dependent on the extract concentration and the exposure time. Similar relationships were observed with the garlic pulp extract. However, the hemp extract was found to be more toxic for nematodes. It caused higher mortality of nematodes at lower concentrations than the garlic one. Differences in the toxicity of different plant extracts have been also found in other studies (Seenivasan 2011, El-Nagdi and Youssef 2013, Chałańska et al. 2013).

It should be noted that in the low concentrations of hemp extracts a temporary paralysis seem to be a characteristic nematode reaction. Hence, the prolonged stay in such extract did not lead to death, and on the contrary -nematodes were able to recover their motoric activity.

The incubation of females in the hemp extracts of different concentrations affected the length of reproduction period and the rate of egg laying, but this did not affect their overall fertility. The hatching efficiency of the juveniles (from the eggs laid by pre-treated in the extracts females) has decreased significantly with the increase of the extract concentration, while similar hatching efficiencies have been observed for the eggs which the females deposited directly in the hemp abstracts. The results showed that low hemp concentrations could stimulate the hatching process, while higher ones, e.g. $5 \%$, had a marked inhibitory effect. Moreover our results indicate the different sensitivity of the development stages (adult or eggs) of $A$. nanus to the extracts.

Our results are in line with the results of other studies showing the concentrationdependent effects of the plant extracts (of hemp, garlic and castor bean) in relation to plant parasitic nematodes (Seenivasan 2011, Adomako and Kwoseh 2013, Chałańska et al. 2013, El-Nagdi and Yossef 2013). Like us, those researchers have observed disruption in the reproduction, dynamics of egg deposition, juveniles hatching efficiency or increasing mortality of nematodes due to plant extract effect.

\subsection{Indirect effects of selected plants on the number of nematodes}

Our results show that the indirect effects of studied plants (both in the form of dead litter and through the root system during planting) on soil nematodes differed from the direct effect by the force and the direction of the induced changes. It turned out, in fact, that the hemp leaf litter in the soil stimulated the development of the nematode leading to an increase in numbers in a relatively short time.

Similarly, a very high rate of reproduction and increase in the abundance (9-10-fold) in comparison with the initial population was found for bacterial-feeding nematodes from genus Rhabditis and predatory nematodes from genus Mononchus in banana cultivation after addition of neem (Seenivasan et al. 2013). However, in the same study it was found a reduction in the number of plant parasites such as Radophulus similis and Helicotylenchus multicinctus. According to these authors, increasing of the abundance of bacterialfeeding nematodes populations lead to an increased competition for space with plant parasites in which the latter seem to lose. Similar antagonistic interactions between plant- and bacterial-feeding nematodes were reported by Stirling (1991). In other studies, the addition of neem leaves led to 
an increase in the population of predatory nematodes Mononchus aquaticus while at the same time reducing root parasites of the genus Meloidogyne (Akthar and Mamood 1993).

The high increase of nematode numbers, Ruess et al. (1998) have explained by decreasing with the time the effect of allelopathic substances (in soil environment rather than in water) in favour of other substances (e.g. carbohydrates) that can stimulate the soil microorganisms and thus indirectly the nematodes (for which microorganisms are the main source of food). A similar mechanism may also operate in our research. As it is well known, hemps are plants which contain more than 400 chemicals, not all of which have toxic effects (Rutkowska and Jamontt 2005).

It is also known that natural plant compounds are easily degradable (Chitwood 2002), which shortens the duration and the strength of their effect. This explains the differences observed in the activity of the same plant in the laboratory and field conditions.

On the other hand Ritzinger et al. (2014) explained the increase of the numbers of bacterial-feeding nematodes in soil in response to the high $\mathrm{N}$ content in the castor meal by the fact that the formation, release and accumulation of toxic to soil nematodes compounds takes time. Taking into account the length of their experiment ( 3 months), one might assume that in our experiment a similar mechanism could be also probable.

Our results indicate that the effect of both plants (castor and lupine) was most visible in the rhizosphere. As it is well known, the rhizosphere is an area of intensive biological, chemical and physical activity that is affected by the compounds secreted by the roots and the microorganisms that feed on these compounds (Kamilova et al. 2006, Kumar et al. 2007). On the list of compounds secreted by the roots are sugars, amino acids, peptides, enzymes, vitamins, organic acids, nucleotides and stimulants as well as other such as saponins, glycosides, hydrocannic (Wielgosz and Szember 2006).
It follows that the effect of root secretions can be both stimulating and toxic not only to microorganisms, but indirectly to nematodes which are the next link in the trophic chain in the soil. This is confirmed by our results, indicating an increase in the number of nematodes in the rhizosphere after 45 days, followed by a decline after next 20 days.

\section{Conclusions}

It has been found that studied plants (hemp, garlic and castor) affect in different ways the selected representatives of free-living soil fauna. Some distinct differences were found between the direct (aqueous extract) and indirect (litter or root system) impact of the plants. Nematodes were the most sensitive to the toxicity of hemp extract and earthworms the least. The strength of the hemp extract showed a clear dependence on its concentration. The garlic extract showed less toxicity to nematodes than the hemp extract did. In soil, both the hemp litter and the castor plants had a positive indirect effect on the numbers of nematodes at least during the experiment.

\section{References}

Akhtar M., Mahmood I., 1993, Effect of Mononchus aquaticus and organic amendments on Meloidogyne incognita development on chilli, Nematologia Mediterranea, 21, 2, 251-252.

Borek S., Galor A., 2015, Rośliny transgeniczne źródłem wysokiej jakości olejów, Kosmos, 61, 477-491. Chałańska A., Łabanowski G., Maciorowski R., 2013, Ocena skuteczności dziatania niektórych substancji i preparatów pochodzenia naturalnego $w$ zwalczaniu wegorka chryzantemowca - Aphelenchoides ritzemabosi (Schwartz, 1911) Steiner i Buhrer, 1932, Prog. Plant Prot./Post. Ochr. Roślin, 53, 3, 563-568. Chitwood D.J., 2002, Phytochemical based strategies for nematode control. Annual Review of Phytopathology, 40, 221-249.

El-Nagdi W.M.A.-E., Youssef M.M.A., 2013, Comparative efficacy of garlic clove and castor seed aqueous extracts against the root-knot nematode, (Meloidogyne incognita) infecting tomato plants, J. Plant Prot. Res. 53, 3, 285-288. 
Flegg J.J.M., Hooper D.J., 1970, Extraction of free -living stages from soil, in: Southey J.P. (ed.) "Laboratory methods for work with plant and soil nematodes", Technical Bulletin of Ministry of Agriculture, Fisheries and Food London, 2, 5-23. Grewal P.S., 1989, Nematicidal effects of some plant -extracts to Aphelenchoides composticola (Nematoda) infesting mushroom Agaricus bisporus, Rev. Nematol. 12, 317-322.

Ilieva-Makulec K., 2013, Biologia, ekologia $i$ możliwości oddziaływania na rozwój nicieni glebowych, in: Tyburski J., Makulec G. (eds) „Fauna gleb użytkowanych rolniczo a ich urodzajność" [Fauna of agricultural soils and their fertility], Wyd. Uniwersytet Warmińsko-Mazurski w Olsztynie, 95-115 [in Polish].

Kamilova F., Kravchenko L.V., Shaposhinkov A.I., Azarova T., Makarova N., Lugtenberg, B., 2006, Organic acids, sugars and L-tryptophan in exudates of vegetables growing on stonewool and their effects on activities of rhizospere bacteria, Mol. Plant-Microbe Interact. 19, 250-256.

Kemper K.J., 200o, Garlic (Allium sativum), The Center for Holistic Pediatric Education and Research, 3-12.

Kumar R., Bhatia R., Kukreja K., Behl R.K., Dudeja S.S., Narula N., 2007, Establishment of Azotobacter on plant roots: chemotactic response, development and analysis of root exudates of cotton (G. hirusitum L.) and wheat (T. aestivum L.), J. Basic Microbiol. 47, 436-439.

Makulec G., Ilieva-Makulec K., 2013, Ogólna charakterystyka fauny glebowej, in: Tyburski J., Makulec G. (eds) „Fauna gleb użytkowanych rolniczo a ich urodzajność" [Fauna of agricultural soils and their fertility], Wyd. Uniwersytet Warmińsko-Mazurski w Olsztynie, 10-34.

Nicholas W.L., 1975, The biology of free-living nematodes, Oxford University Press, $219 \mathrm{pp}$.

Preacher K.J., 2001, Calculation for the chi-square test: An interactive calculation tool for chi-square tests of goodness offit and independence [Computer software]. Available from: http://quantpsy.org.
Ritzinger C.H.S.P., De Ley P., Ploeg A.T., McSorley R., De Ley I.T., 2014, Impact of castor meal on root-knot and free-living nematodes, Sci. Agric. 71, 4, 274-28o.

Ruess L., Michelsen A.; Schmidt I.K., Jonasson S., Dighton J., 1998, Soil nematode fauna of a subarctic heath: potential nematicidal action of plant leaf extracts, Applied Soil Ecology, 7, 111-124.

Rutkowska M., Jamontt J., 2005, The Role of cannabinoid system in the physiology and the pathophysiology of the central nervous system, Advances in Clinical and Experimental Medicine, 14, 6, 1243-1252

Seenivasan N., 2011, Bio-efficacy of antinemic plants against root-knot nematode in medicinal coleus, Journal of Eco-Friendly Agriculture, 6, 1, 92-96.

Seenivasan N., Manoranjitham S.K., Auxilia J., Soorianathasundaram K., 2013, Management of nematodes in banana through bio-rationale approaches, Pest Management in Horticultural Ecosystems, 19, 1, 38-44.

Siudem P., Wawer I., Paradowska K., 2015, Konopie $i$ kannabinoidy [Cannabis and cannabinoids] Farmacja współczesna, 8, 1-8.

StatSoft, Inc. (2014). STATISTICA (data analysis software system), version 12. www.statsoft.com.

Stirling G.R., 1991, Biological control of plant parasitic nematodes, Chichester, England, $282 \mathrm{pp}$.

Thoden T.C., Boppré M., Hallmann J., 2007, Pyrrolizidine alkaloids of Chromolaena odorata act as nematicidal agents and reduce infection of lettuce roots by Meloidogyne incognita, Nematology, 9, 3, 343-349.

Wielgosz E., Szember A., 2006, Występowanie naturalnych zespołów drobnoustrojów glebowych w strefie przykorzeniowej rolin wykorzystywanych w zagospodarowywaniu terenów przydomowych, Annales UMCS, Sec. E, 61, 75-92.

Wuyts N., Swennen R., De Waele D., 2006, Effects of plant phenylpropanoid pathway products and selected terpenoids and alcaloids on the behavior of the plant-parasitic nematodes Radopholus similis, Pratylenchus penetrans and Meloidogyne incognita, Nematology, 8, 1, 89-101. 


\section{Rośliny o znanych antagonistycznych właściwościach przeciwko szkodnikom: w jaki sposób wpływają na wolnożyjące gatunki fauny glebowej?}

\section{Streszczenie}

Praca dotyczy badań nad wpływem trzech gatunków roślin na wybrane wolnożyjące gatunki fauny glebowej. Zbadano bezpośredni wpływ wyciągu wodnego z liści konopi siewnych i miazgi czosnku na przeżywalność nicieni, wazonkowców i dżdżownic oraz w przypadku nicieni na płodność, dynamikę produkcji jaj i skuteczność wylęgania się jaj. W eksperymentach mikro- i mezokosmosowych natomiast oceniano pośrednie oddziaływanie ściółki z liści konopi oraz uprawy rącznika pospolitego na liczebność nicieni.

Wyniki biotestów potwierdziły antagonistyczne działanie ekstraktów wybranych roślin. Najbardziej wrażliwe na substancje czynne wyciągu z liści konopi okazały się bakteriożerne nicienie Acrobeloides nanus, mniej wrażliwe wazonkowce Enchytraeus sp., a najbardziej odporne dżdżownice Dendrobaena sp. W przypadku nicieni i wazonkowców stwierdzono zależność toksycznego działania od stężenia wyciągu oraz czasu ekspozycji. Inkubacja samic A. nanus w wyciągach o różnym stężeniu wpływała na tempo składania jaj, długość okresu reprodukcji, skuteczność wylęgania się osobników młodocianych, natomiast nie miała wpływu na ich całkowitą płodność.

Obecność ściółki z konopi w glebie jak i uprawa rącznika pospolitego wpływały pozytywnie na liczebność nicieni. Nasze wyniki pokazały, że pośredni efekt badanych roślin (zarówno w postaci ściółki, jak i poprzez system korzeniowy) różnił się od bezpośredniego działania zarówno intensywnością jak i kierunkiem wywołanych zmian.

\section{Słowa kluczowe}

ekstrakty roślinne, nicienie bakteriożerne, wazonkowce, dżdżownice, biotesty, eksperymenty mikro- i mezokosmosowe 